\title{
Aten Temples out of Amarna
}

\section{Ahmed fathy saddik}

Director of archaeological documentation in Mallawi

\begin{abstract}
The Atenism has been presented as a monotheistic religion associated with the presence of Akhenaten, who played the role of mediator. This religion began in Luxor and then moved with Akhenaten to El-Amarna. It has also been argued that this religion did not spread beyond the hill of El-Amarna, which was its only center, however, archaeological evidence from different sites in Egypt has demonstrated the opposite. The aim of this paper is to present a further interpretation of the Atenism and its spread all over Egypt. Archaeological data concerning the existence of archaeological structures dedicated to Aten out of El-Amarna will be the focus of this paper.
\end{abstract}

\section{Aten Temples}

The first impression among many scholars of the Amarna Period was that the Aten religion was associated with the existence of Akhenaten himself. Aten was worshipped only in Amarna and there are few shrines dedicated to his cult in Amarna and in Karnak. ${ }^{1}$ However, current archaeological evidence contradicts these ideas. The most commonly held conception is that all religious elements concerning the worship of the Aten were centred at Akhetaten, once the court had moved to this site. The temples situated here are the best documented of all the Amarna temples.

Four major temples at Akhetaten are known, along with the many altars and shrines within the city of the Aten ${ }^{2}$ and these are:

pr itn The House of the Aten

pr hi The House of Rejoicing

gm-p3-itn He who Found the Aten

Hwt itn The Mansion of the Aten 
In Amarna, the most common scenes were of Akhenaten, his wife Nefertiti and his daughters during their daily worship. This was evident in most of the temple, but what about the other Aten temples? How Aten was worshipped? Do Akhenaten and his family still have the main concern of the temple scenes or are there local influences on these temples out of Amrana?

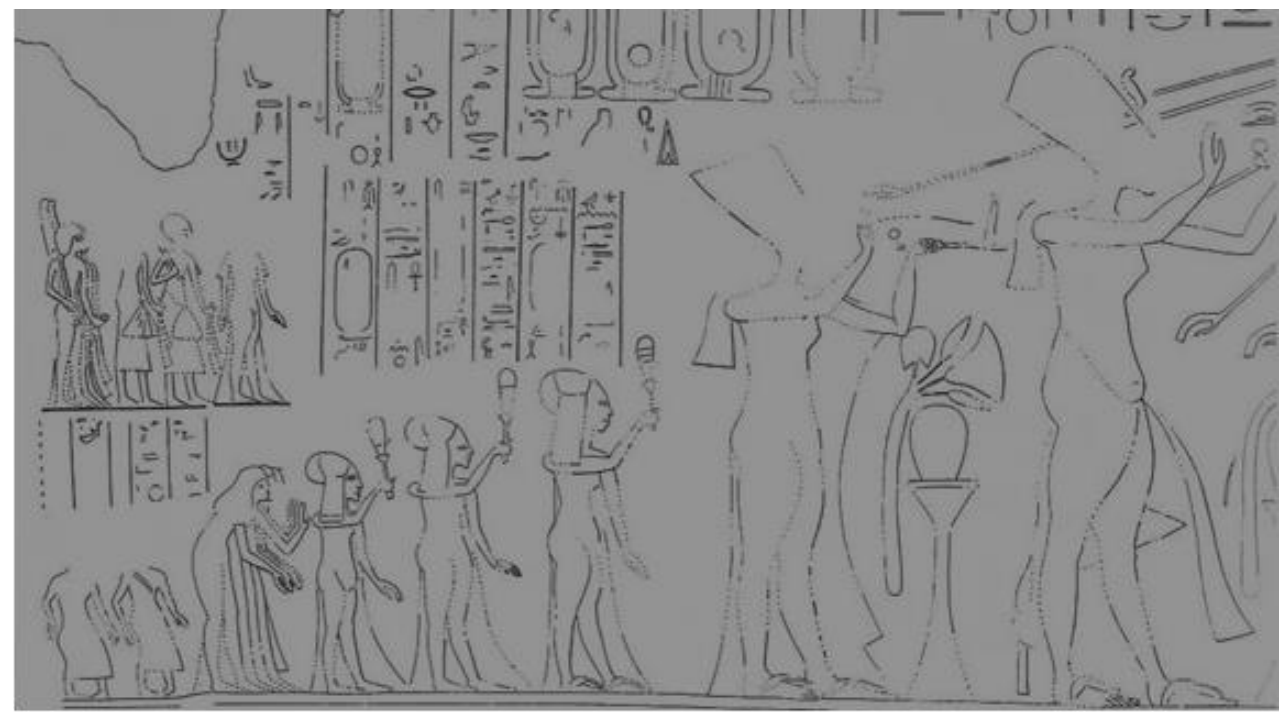

Fig. 1. A scene from the tomb of Meryra 1

(Northern Tomb 4 at Amarna) showing Akhenaten ,Nefertiti and their daughters participating in the service to the Aten (After, Davies, 1903,Part 1, Plate XXII)

What about the old state capital of Memphis in Lower Egypt? What happened to its religious centres? These are the most important questions that will be dealt with in this paper.

there is evidence to argue that temples to Aten out of Akhetaten existed, particularly in Memphis. ${ }^{3}$ Blocks with the late form of the name of Aten, which was used after year 9 of Akhenaten's reign, was found. ${ }^{4}$ This shows that there is evidence for the construction of temples to the Aten outside Akhetaten after the radicalization of Akhenaten's reforms and his move to Middle Egypt.

Some argue that Amenhotep II may have constructed an estate established to Aten supporting an idea of establishing a temple to Aten in Delta region. This would then mean that the temple to the Aten, at Memphis or at Heliopolis, was of long standing before the reign of 
Akhenaten, and he just reconfirmed its use when he became a pharaoh. It would also make sense to have a temple to the Aten within the vicinity of Memphis, because otherwise where would Akhenaten worship his god when he was in residence in this city?

A round-topped stela (fig.2) was discovered at Heliopolis. On this stela, Akhenaten and his family are depicted worshipping Aten. ${ }^{5}$ This then raises a question regarding temples to the Aten in Lower Egypt: were there Aten temples at both Memphis and at Heliopolis? Current evidence seems to support the idea that this was the case.

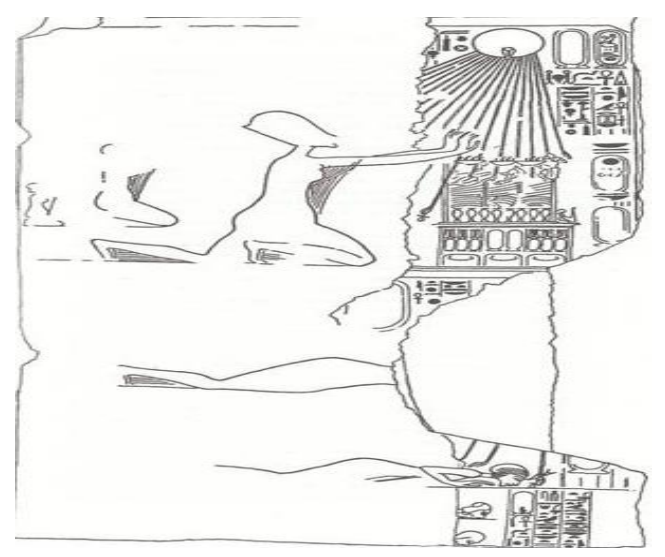

Fig. 2. Line drawing of a stela found at Heliopolis depicting the Amarna Royal Family bowing down before the Aten (After, Aldred, 1988, 274)

Thre is at Heliopolis a new temple to the Aten was established, whilst at Memphis "one of the new fangled shrines" was constructed. ${ }^{6}$ Interestingly enough, at the beginning of the $21^{\text {st }}$ Millennium, the tomb of Meryneith was discovered at Saqqara in a joint excavation by the Leiden Museum and Leiden University. The titles of this man include the epithets of "Steward of the Memphite Aten Temple" and "High Priest of Aten".

In 2003 another tomb was found, again at Saqqara, by the Mission Archéologique Française du Bubasteion, directed by Alain Zivie. This tomb was of Rehatiay, who was the "Scribe of the Treasury of the Temple of Aten in Memphis". ${ }^{8}$ These two tombs then, suggest that the idea of a shrine being at Memphis is now in error, as the tombs give concrete evidence of a temple at Memphis, although the size of it remains unclear. 
From the evidence provided by the tombs which have recently been found, it would appear that scholars are now looking for two possible temples; one in Memphis and the other at Heliopolis. This newly found evidence is beginning to shed light on the fact that there were more than just the previously known temples at other cities. Else where in Lower Egypt, There is another opinion proposed a third site for a structure erected to the Aten at Sam-Behdet in the northern part of the Delta. ${ }^{9}$

In Saqqara, a tomb for a man named Ptah-m-wia discovered by the joint Leiden Museum of Antiquities and the Leiden University mission. Ptah-m-wia's tomb is located to east of the tomb of Meryneith. Ptah-mwia's titles include the title of the "Royal Butler". From the style of its reliefs, the tomb has been dated to the reign of Akhenaten. ${ }^{10}$ This discovery of this tomb raises at least two questions; Was he a citizen of Akhetaten and buried at Saqqara? That might explain where people of his status may have been buried, since tombs of many people who served Akhenaten have not been found at Amarna. Was his place of work at the royal palace at Memphis? This might explain that there might have been a palace in Memphis where the royal family of Amarna used, and, therefore, evidence that they did indeed make visits to this city and were not confined to the city of Akhetaten.

Certain temples dedicated to Aten are found in the Upper Egyptian city of Thebes. At Karnak there were four main structures dedicated to the Aten mentioned in surviving texts from Karnak. Nothing of these structures still remain above the ground. These blocks of these structures for Aten have been taken for the building of other structures in Karnak or out of it. In Thebes, structures for Aten were found and these are as follows: 
Hwt-bnbn

The Mansion of the Benben

rwd-mnw-n-itn-r-nḥh $\quad$-Strong are the monuments of the Aten forever

Tni-mnw-n-itn-r-nḥḥ

-Exalted are the monuments of the Aten forever ${ }^{11}$

There are also references to four other structures, including a "Broad hall" and a "House of Rejoicing", which may allude to buildings which were already erected when Akhenaten ascended to the throne. Although mentioned numerous times, these four structures have not been described in any text discovered so far, or their purposes indicated. ${ }^{12}$

When the court was moved to Akhetaten, the temples at Thebes were abandoned for the next 12 years and remain silent. ${ }^{13}$ This may not be the case though. Not only are there blocks at Memphis with the name of the Aten which was used after the $9^{\text {th }}$ regnal year of the king, but also at Thebes there is a stray block with a similar carving. ${ }^{14}$ The evidence presented that the temples at Thebes were not abandoned with the move to Akhetaten, but that construction continued in the city once dominated by Amun. These temples would be required for use when the royal family and court came to Thebes on one of their visits. What is difficult to specify is whether all the temples at Karnak continued to function at full capacity, or if one or two or more of them may have been chosen to remain functional, whilst the others stood idly by. Also during the Amarna Period, Talatat blocks from Karnak where scenes depicting the houses of Theban officials, into which are incorporated private shrines to the Aten. ${ }^{15}$ It is difficult to know whether these officials then went with Akhenaten to his new city, or whether they continued to play a part at Karnak and in the temples of the Aten there in the absence of their pharaoh.

For many years there were misconceptions regarding the presence of temples to the Aten at Thebes. In the 1890s, whilst clearance of the great pylon built by Rameses II was being carried out at Luxor temple, 
archaeologists found the pylon full of Talatat depicting scenes of life and worship at the temples of the Aten at Karnak.

A similar discovery was also made at Medamud, a city about 8 miles north east of Karnak in the 1920. During the excavations at this site, once again, several hundred Talatat were discovered. The presence of these Talatat was also interpreted as evidence for a temple to the Aten having been erected at this site. ${ }^{16}$ Later on it was concluded that these sites had never had an Aten temple, but rather that sometime after Horemheb's reign these blocks had been carried away from Karnak and deposited at these sites as infill. ${ }^{17}$

At the beginning of his reign Akhenaten founded a town at Sesebi, which he dedicated to the worship of the god Amun, when he was still known as Amenhotep IV. It did not take long though for this temple to be adapted to serve the cult which Akhenaten was promoting, that of the Aten. ${ }^{18}$ The excavation in 1937 and 1938 discovered an approach from the east of the town, being flanked by four stone bases, presumably for statues or possible offerings. It was a similar arrangement to the approach of the smaller temple, the Hwt itn, found at Amarna. ${ }^{19}$ There are also some suggestions that there might be more temples at both Tabo and Kerma in Nubia as well. ${ }^{20}$

In the central cataract region of Nubia, and for the next thousand years, a city was to survive under the name "Gem-Aten". It is believed by some that this was a new city founded by Akhenaten for the sole purpose of worship to the Aten in Nubia. ${ }^{21}$ The fact that the name of the town survived for such a length of time, and during the reigns of many pharaohs could be interpreted as evidence to show how devoted this region of Nubia was to the sun god, in the form of the Aten. Or, alternatively, how little the succeeding Egyptian pharaohs felt they needed to interfere in the name of towns so far south in their extensive empire. 
At Kawa, near to the modern town of Dongola and south of the third cataract, there is indeed evidence of not only a town, but also of a temple to the Aten. ${ }^{22}$ Although archaeological records of this area are limited, it appears that the city was called Gem-Aten, whilst the temple was named after Akhenaten's temple at Karnak, gm-p3-itn, which means 'the Aten is found'. ${ }^{23}$ This site is another one in any case to add to the numerous towns in Nubia which are known to have had a temple to the Aten.

Currently, this temple is the furthest south of any of the Aten temples unearthed in Nubia, with the exception of the temple of the Aten which is believed from historical records to have been situated at Napata (Gebel Barkal), but has yet to be discovered. These temples were either founded by Akhenaten, or at the very least reconfirmed by Akhenaten, having been founded earlier, possibly by Amenhotep III, or even by one of his predecessors. $^{24}$

It seems incredible to think that there are up to at least five known temples to the Aten in Nubia. It is quite probable that there could be more Upper and Lower Egyptian temples which have yet to be discovered or recognised as such. The fact that so many have been located in Nubia raises some more questions. Is this due to the dry conditions which have preserved them or was it perhaps that the Nubians were more receptive to the idea of the Aten as a god and were more willing to.

\section{Conclusion}

\section{There is an opinion saying that"Akhenaten has all the classic signs of being} monolatrous, i.e. a person who worships only one god without excluding the belief in other gods". ${ }^{25}$ This word seems to describe Akhenaten better than all the others employed in trying to understand the position of his religious dogma and his relationship between the one god and the many. 
Scholarship has given the view that once the move to Akhetaten had been made and the temples there constructed, the temples at Karnak to the Aten were no longer used as places of worship.Yet evidence has suggested that these temples did continue to function for those who lived at Thebes and wished to worship the Aten.

There is also archaeological evidence that there was also a temple at Heliopolis, which may even have been constructed as early as the reign of Amenhotep II. From recent tombs located at Saqqara, titles of tomb owners such as "Steward of the Memphite Aten Temple", "High Priest of the Aten" and "Scribe of the Treasury of the Temple of Aten in Memphis" can be used to ascertain that there were at least two temples to the Aten in Lower Egypt, with at least another one in the Delta Region.

In Nubia, however, there is evidence for at least a further four temples to the Aten from archaeological records and one additional temple, at Gebel Barkal, from historical records. Even if these were the only temples which were constructed to the worship of the Aten, this refutes the current concept that adherents to the worship of the Aten were relatively few in number and located in a small area within Egypt, e.g. Akhetaten.

\section{Bibliography}

Baines J., 1998, 'The Dawn of the Amarna Age', in D. O'Connor and E.H. Cline (eds.), Amenhotep III: Perspectives on His Reign, London: Ann Arbor, 287-297.

Breasted J.H., 1906a, Ancient Records of Egypt, Volume 2: The Eighteenth Dynasty, Chicago, University of Chicago Press.

Cottevieille-Giraudet, Rémy 1936, Rapport sur les fouilles de Médamoud (1932): les reliefs d'Aménophis IV Akhenaton, Fouilles de l'Institut Français d'Archéologie Orientale 13, Le Caire.

Foster J.L., 1999, 'The New Religion', in: R.E. Freed, Y.L. Markowitz, S.H. D’Auria (eds.), Pharaohs of the Sun - Akhenaten, Nefertiti, Tutankhamen, London: Thames and Hudson Ltd., 96-109.

Giddy L., 2003a, 'Digging Diary', Egyptian Archaeology 22, pp. 31-33

Giddy L., 2003b, 'Digging Diary', Egyptian Archaeology 23, pp. 29-34 
Kendall T., 1999, ‘Foreign Relations’, in R.E. Freed, Y.L. Markowitz, S.H. D’Auria (eds.),

Pharaohs of the Sun - Akhenaten, Nefertiti, Tutankhamen, London, Thames and Hudson

Ltd.

Martin G.T., 1991, The Hidden Tombs of Memphis: New Discoveries from the time of Tutankhamun and Ramesses the Great, London, Thames and Hudson.

Montserrat D., 2000, Akhenaten: History, Fantasy and Ancient Egypt, London and New York, Routledge.

Morkot R., 1988, 'The Excavations at Sesebi (Sudla) 1936-1938', Beiträge zur Sunadforschung 3, pp. 159-63.

Redford D.B., 1984, Akhenaten: The Heretic King, Princeton: Princeton University Press

Spencer P., 2007, 'Digging Diary', Egyptian Archaeology 31, 25-29.

Stevens A., 2006, Private Religion at Amarna - The Material Evidence, British Archaeological Reports (BAR), International Series 1587, Oxford: Archeopress.

Van Dijk J., 2000, 'The Amarna Period and the Later New Kingdom (c1352-1069 B.C.)', in I. Shaw (ed.), The Oxford History of Ancient Egypt, Oxford, Oxford University Press, $272-313$

Watterson B., 1999, Amarna: Egypt's Age of Revolution, Stroud: Tempus Publishing Ltd.

\footnotetext{
${ }^{1}$ Foster J.L., 1999, 'The New Religion', in R.E. Freed, Y.L. Markowitz, S.H. D’Auria (eds.), Pharaohs of the Sun-Akhenaten, Nefertiti, Tutankhamen, London, Thames and Hudson Ltd, 108.

${ }^{2}$ Watterson B., 1999, Amarna: Egypt's Age of Revolution, Stroud: Tempus Publishing Ltd, 69-70.

${ }^{3}$ Martin G.T., 1991, The Hidden Tombs of Memphis: New Discoveries from the time of Tutankhamun and Ramesses the Great, London: Thames and Hudson, 30.

${ }^{4}$ Van Dijk J., 2000, 'The Amarna Period and the Later New Kingdom (c1352-1069 B.C.)', in I. Shaw (ed.), The Oxford History of Ancient Egypt, Oxford, Oxford University Press, 286.

${ }^{5}$ Redford D.B., 1984, Akhenaten: The Heretic King, Princeton: Princeton University Press, 139

${ }^{6}$ Redford, Akhenaten, 139.

7 Giddy L., 2003b, 'Digging Diary', Egyptian Archaeology 23, 30.

${ }^{8}$ Giddy L., 2003a, 'Digging Diary', Egyptian Archaeology 22, 32.

${ }^{9}$ Redford, Akhenaten, 139.

${ }^{10}$ Spencer, P., 2007, 'Digging Diary', Egyptian Archaeology 31, 25.

${ }^{11}$ Redford, Akhenaten, 63.

${ }^{12}$ Redford, Akhenaten, 63.

${ }^{13}$ Redford, Akhenaten, 142.

${ }^{14}$ Van Dijk, in: Shaw (ed.), The Oxford History of Ancient Egypt, 286.

${ }^{15}$ Stevens A., 2006, Private Religion at Amarna - The Material Evidence, British Archaeological Reports (BAR), International Series 1587, Oxford: Archeopress, 8.

${ }^{16}$ Cottevieille Giraudet Rrmy,1932

${ }^{17}$ Redford, Akhenaten, 66-71.

${ }^{18}$ Kendall T., 1999, 'Foreign Relations', in R.E. Freed, Y.L. Markowitz, S.H. D'Auria (eds.), Pharaohs of the Sun - Akhenaten, Nefertiti, Tutankhamen, London: Thames and Hudson Ltd, 157.

${ }^{19}$ Fairman, H. W., 1938, Preliminary Report on the Excavation at Sesebi (Sudla) and Amarna West, AngloEgyptian Archaeology 24, London, Egypt Exploration Society, 152.

${ }^{20}$ Stevens, Private Religion at Amarna, 5

${ }^{21}$ Breasted J.H., 1906a, Ancient Records of Egypt, Volume 2: The Eighteenth Dynasty, Chicago: University of Chicago Press, 388.
} 
${ }^{22}$ Baines J., 1998, 'The Dawn of the Amarna Age', in D. O’Connor and E.H. Cline (eds.), Amenhotep III: Perspectives on His Reign, London: Ann Arbor, 297.

${ }^{23}$ Kendall, In Freed et al, Pharaohs of the Sun, 157.

24 Baines, in: O'Connor and Cline (eds.), Amenhotep III, 287.

${ }^{25}$ Montserrat D., 2000, Akhenaten, 41. 